UDC: 81'42; 070(410):81'27

\title{
- HONESTY VS GREED, MACCA VS MUCCA: OTHERING IN TWO BRITISH NEWSPAPERS
}

\author{
THOMAS HAWES 1 \\ Ludwig-Maximilians-University, \\ Institute for English Philology, \\ Munich, Germany
}

JAMES OWENS
Kanda University of International Studies,
English Language Institute, Japan

Feministi odavno osuđuju trivijalizaciju i seksualizaciju žena u britanskim novinama, ali su se verovatno nedovoljno usredsredili na ono što ponekad deluje kao istinska demonizacija žena visokog profila. Na primer, smrt Ejmi Vajnhaus leta 2011. na prvi pogled ne čini se sasvim nepovezanom sa godinama besomučnog ogovaranja komeje bila izložena, naročito u listu „San". Ovaj članak bavi se uporednim ispitivanjem konstruisanja "druge" Heder Mils, bivše supruge Pola Makartnija, u dva članka, iz „Sana" i iz "Gardijana". Kako bismo sproveli višeslojnu jezičku analizu upotrebićemo niz funkcionalno-gramatičkih sredstava: tranzitivnost, da bismo uporedili uloge dodeljene Milsovoj i Makartniju; nominaciju, da bismo videli kako ih nazivaju; kategorizaciju u vezi sa stereotipima sa kojima ih povezuju; i procenu vrednosti da bismo pokazali da li ih prikazuju pozitivno ili negativno. Rezultati ukazuju na to da postoji veliki disbalans u prikazu pomenutih poznatih ličnosti. Postavlja se pitanje zašto je to tako. Da li je Milsova toliko monstruozna, a Makartni anđeo? Ili se radi o tome da priča o razvodu, u kojoj se junak stavlja naspram zlikovca, pruža savršeno sredstvo za posredno širenje ideologije novina i slanje ranije postojeće poruke.

Ključne reči: kritička analiza diskursa, funkcionalna gramatika, jezik i mediji.

\section{INTRODUCTION}

This study seeks to throw light upon the representation of women in our media by comparing parallel articles in two British newspapers, The Sun and The Guardian.

1 Kontakt podaci (Email): Thomas.Hawes@anglistik.uni-muenchen.de 
The former is the UK's most popular tabloid daily, the latter a broadsheet generally considered liberal-centrist or left-wing, depending on one's politics. Our study looks at the extent to which, if at all, the woman is more often trivialised and negatively portrayed than the man, above and beyond what is strictly warranted by the facts of the case. It also examines whether this is more pronounced in the tabloid than in the broadsheet and, if so, how. Our analysis is in part quantitative (counting and comparing instances) but also qualitative, interpreting the data and placing them in the broader context of 0thering, particularly in The Sun. The latter is thought to have a daily audience of 7,694,000 (NRS 2010), including reading online and by borrowing others' copies of the paper. Judging by sales, it is the most representative of British tabloids, indeed the archetypal tabloid. The Sun's standing within the country, and its potential to influence public opinion, may account in part for the frequency with which it has been criticised by linguists, including for its negative representation of women (e.g. Clark 1998). Its standing alone warrants critical monitoring by linguists, but where it appears that the newspaper is presenting a warped version of reality and, worse, that this warp runs along gender lines, no further justification is needed.

What gave the impetus for this study was a survey testing public attitudes to sexual assault, in which $56 \%$ of interviewees considered '...there are some circumstances where a victim should accept responsibility [for being raped]' (Opinion Matters 2010: 9). Our interest ignited, we examined 22 articles in The Sun and The Guardian and recorded our findings in a broader but less detailed article, Sexism: Do our Newspapers have a Choice? This study found a marked overall difference between the degree of trivialisation and sexualisation in the two newspapers and therefore, more importantly, suggested that the decision to portray women in a certain way was a matter of choice rather than of linguistic normality or necessity. The present paper now conducts a related examination that is narrower but deeper, going into greater detail regarding the mechanisms involved, and seeking to show through numerous examples how the newspapers construct their particular styles of representation.

We research loosely within the tradition of CDA (critical discourse analysis), which takes the view that language production always involves choice on the part of the speaker/writer and actually creates divisions and definitions. It assumes that "...the English language allows us to describe the same event in many different ways" (Richardson 2007: 56) and explores "...text in terms of what is present and what could have been but is not present" (ibid: 38). The implication here is that "... reality (including such aspects of it as power and gender relations) is constructed in and through discourse" (Cameron 2001: 51). In this instance the chunk of real world at issue is the divorce of two British celebrities, Heather Mills and Paul McCartney. The former is a high profile model and charity campaigner, the latter a world famous musician. The two articles, one from each of the two newspapers, refer to the same events, probably drawing upon the same information sources. Our study asks how it is - in a technical linguistic sense - that they create such differing portrayals. It also asks what ideological agendas might be behind these respective portrayals. 


\section{OTHERING WOMEN IN THE MEDIA}

Here we briefly summarise, firstly, a selection of feminist criticism of media portrayals of women generally and, secondly, 0thering in The Sun and examples of the more specific Othering of women. A substantial body of feminist literature insists that gender is an '...ongoing, reaffirming process' (Benwell 2002: 154) rather than fixed by nature, and that 'gendered dichotomies' and 'stereotypical representations' (Litosseliti 2002: 133) of men and women must be regarded with suspicion. According to Butler (1990: 25), gender is something one 'does'. Defining it has in the past been the preserve of what feminists see as a male-dominated elite. Therefore, in the words of Marshment (1993: 123), 'representation [including the representation of women and men] is a political issue'.

One complicating factor is the claim that women can themselves internalise maledominated ideology and '...encourage their own exploitation' (Jule 2008: 35). Another is that there is disagreement within feminism, such that '...no work can be guaranteed to deliver an acceptably feminist message to all feminists' (Marshment 1993: 139). Some feminists call for images of 'strong' women to be portrayed in the media. Others dismiss such images as unrepresentative of the majority of women and counter-productive. Some consider images of women as 'sex-objects' as demeaning, while others consider them as empowering (Marshment 1993: 130).

Mulvey (1975), focusing on 'gaze' in cinema, claims women are often defined by their appearance and how it may be rated in terms of male desire. Two very different positions are constructed from this perspective: men who gaze, and women who are gazed at. Women are more likely to be portrayed with a focus on the physical, particularly with sexual connotations, whereas men are more often described in terms of their activity. Some consider that gaze theory implies a situation where '...the woman simultaneously controls the desire of the man' (Marshment 1993: 146), others that this emphasis on women's beauty and self-image helps to maintain male dominance and reifies women as (mere) 'objects of male desire' (Caldas-Coulthard 1996: 255).

Additionally, feminists have argued that the media feature disproportionate levels of trivialisation and/or negative portrayal of women. Proponents of critical discourse analysis seek to challenge such negative portrayals by '...exposing the often subtle role of discourse in the construction and maintenance of injustice, inequality and domination' (Litosseliti \& Sunderland 2002b: 19). One study targeting negative representation of women in the media is Clark (1998), which examines reports of sexual violence against women in The Sun and identifies three main strategies the newspaper employs to 'manipulate blame' (p194). One of these is to portray 'good men' (those presented '...in terms of social normality' e.g. 'husbands' - p184) as being tempted by 'bad women' (i.e. those implied to be promiscuous or 'unrespectable'). Clark finds that the tabloid emphasises female 'culpability' by foregrounding women and their actions, or publishing erotically encoded photos of them, as did our own previous study Sexism: Do our Newspapers have a Choice?

With particular reference to The Sun, Hawes (2010) claims that celebrities are exploited in the media to cultivate an 'us and them' mentality. The way this functions is that, firstly, a cult of celebrity is encouraged in the newspaper by regularly focusing on 
high-profile individuals and groups; then this cult of celebrity is exploited by including or excluding, highlighting or demoting specific news items in line with the paper's ideological priorities; next particular people are singled out for transformation into icons of what the paper considers positive or negative values; finally extra elements may be attached at will to these icons in order to endorse or attack political and other opinions as expedient. What is important is that all this may be less than obvious to consumers while they are concentrating on the said celebrities (Hawes 2010: 1).

The Sun posits a binary polarity between us and them, between friends and outsiders, fostering an association between any given person(s) and one or other opposing pole, and thereby has a ready-made argument for or against them. In this way readers may be ideologically positioned to accept what has traditionally been known as '0thering'. This notion has been employed by feminists who criticise male patriarchal thinking's inability to perceive woman except as man's negative mirror image or '0ther' (e.g. de Beauvoir 1949). 'In a similar way to friends or family negotiating through the medium of gossip which of their acquaintances belong to a favoured in-group and which they disapprove of, newspapers consistently portray specific people as favoured or disfavoured, thereby progressively introducing their readers into a synthetic in-group "community"' (Hawes 2010: 7) and positioning them against an opposing out-group.

Approximately one in ten grammatical subjects in The Sun thematises a friend, while outsiders account for about one in every fifteen (Hawes 2010: 10). The former include British royals and soldiers, sportspeople who are seen as serving Britain well, etc. 'Outsiders' in Hawes' study comprise predominantly Islamic fundamentalists in the UK, criminals, and celebrities behaving badly. In terms of 'behaving badly', it is typically the behaviour of female celebrities, such as Amy Winehouse, rather than males, that is at issue.

A favoured tactic in The Sun is the juxtaposition of articles focusing on 'friends' and 'outsiders'. For instance, a double-page article on pages 4-5 of The Sun on 12.9.2008, under the title 'Slammer House of Horror', comprises a photo of women 'lifers' in Holloway Prison, complete with arrows to smaller photos of the individual women around the outside, as well as short texts outlining their crimes. This double-page 'monster' feature is juxtaposed with a double-page 'heroes' feature based on Theo Walcott's hat-trick in England's 4:1 football victory over Croatia shortly before. The Walcotts are portrayed as an ideal family, compared to the women in Holloway as a holy family versus an unholy family. Two pages later, in the same issue, a cartoon and caption under the heading Amy moves to a Farm depict Amy Winehouse as a scarecrow in a field. On the following day, another article attacks her behaviour under the heading Winehouse of Horror. It states (and one should remember she was only in her early twenties at that time, perhaps lacking the life experience necessary to deal with such media vilification): 'AMY WINEHOUSE looked a right fright on her latest night out. The bongoed zombie took to London's Camden with monster mate' (The Sun, 13.9.2008: 18).

\section{DATA AND METHODOLOGY}

Our two texts from 2008 cover the same incident, namely an appeal court judge's rejection of a wife's claims for better financial terms from a divorce settlement. The Sun 
text comprises 1255 words including 183 processes, while the Guardian text has 822 words and 131 processes. Our research questions were as follows:

1. in what ways, if at all, is the female protagonist more negatively portrayed than the male?

2. to what degree, if at all, is this more pronounced in The Sun than in The Guardian?

3. what do the results suggest about the newspapers' portrayal of women as opposed to men?

Our study is based on the functional-grammatical theory of Halliday (1985/94) as reformulated by Thompson (2004), as well as on analytical categories from van Leeuwen (1996). We discuss, stage-by-stage, certain issues arising out of our analysis. The specific methodological tools comprise:

- Transitivity, which relates to Halliday's experential metafunction and is most often described as an analysis of 'Who/what does what to whom/what?'. It studies the processes through which the various actors act upon each other and upon their environments. Conducting transitivity analyses allows us to explore in greater detail how various entities (particularly people) are positioned in relation to each other, ie where the writer's bias lies;

- Nomination in Van Leeuwen's 1996 model asks "what are the ways in which social actors can be represented in English discourse? Which choices does the English language give us for referring to people?" (p32). For example, it looks at the way people are named: by family name only ("formal nomination"), full name ("semiformal") or given name only ("informal"). A writer also has the choice available to nickname or "titulate" (e.g. titles such as Dr., Ms. ...etc).

- Categorisation is more complex and can be broken down into two distinct groups: Functionalisation, which refers to "...social actors... in terms of an activity, in terms of something they do, for instance an occupation or role" (Van Leeuwen, 1996: 4), and Identification, which instead defines people "...not in terms of what they do, but in terms of what they are" (p54). There are three main sub-categories of identification: Classification is the labelling of actors in terms of social categories, typically gender, age, class, wealth, sexuality, race and religion, although other more subtle categories also exist. Relational identification describes people in relation to one another (e.g. friend, relative, workmate, sexual partner...etc), while Physical identification "represents social actors in terms of physical characteristics which uniquely identify them in a given context" (p57), such as hair colour, height and level of attractiveness.

- Appraisement, finally, refers to instances where people are defined "...in terms which evaluate them" (p58), as good or bad, right or wrong, desirable or undesirable... etc. It can also help to reveal the "value system" (Hunston \& Thompson 2000: 6) a writer, consciously or otherwise, encodes in his/her text, since "...evaluations of good and bad are often dependent on the value-system underlying the text" (p22). 


\section{DISCUSSION}

Both texts are largely negative in their representation of Mills, though The Sun is more directly evaluative in its portrayal, its very headline referring to her as 'lying Mills'. The Sun gives itself licence to make assumptions such as that the judge '...could barely conceal his contempt for Mills...' It injects additional evaluation into his verdict, claiming in capital letters that he 'SAVAGED', 'BLASTED', and 'CONDEMNED' her, and also employs sub-headings to refer to her, such as 'Humiliating' and 'Volatile'. The Guardian on the other hand, uses neither subtitles nor capitalised words, and avoids additional evaluation of Mills, printing the judge's actual evaluation of her, as in the headline: 'Judge found Heather Mills "less than candid"...'

Whereas The Sun may begin with a negative claim (e.g. 'HEATHER MILLS tried to CON husband...') and contextualise it afterwards ('...it was sensationally revealed...'), The Guardian tends to do the opposite by beginning sentences with, for example, 'The ruling revealed...' This has the effect, in the broadsheet, of prioritising the report rather than the action and this is confirmed by Table 1, below, which shows that the most frequent process in The Sun is Material (with or without a Goal) whereas in The Guardian it is Verbal. These slight differences seem to suggest there is more 'doing' in the tabloid version, whereas the broadsheet frames most of its 'action' within the words of others and also has relatively higher Mental rates (7\% vs $4 \%$ in The Sun). Proportionally, the processes themselves are similar, probably because they share and frequently quote directly from the same court material.

\begin{tabular}{|l|l|l|l|l|}
\hline Process & The Sun & $\%$ & The Guardian & $\%$ \\
\hline Material(+Goal) & 31 & 17 & 21 & 16 \\
\hline Material(-Goal) & 38 & 21 & 20 & 15 \\
\hline Verbal & 66 & 36 & 52 & 40 \\
\hline Mental & 8 & 4 & 9 & 7 \\
\hline Relational-attributive & 29 & 16 & 25 & 19 \\
\hline Relational-identifying & 9 & 5 & 2 & 2 \\
\hline Existential & 2 & 2 & 2 & 2 \\
\hline TOTAL & 183 & & 131 & \\
\hline Word Count & 1254 & - & 819 & - \\
\hline
\end{tabular}

Table 1: Process types

\subsection{ACTIVE MILLS}

Perhaps surprisingly, yet consistent with the findings of our article 'Sexism: Do our newspapers have a choice?' and also with a study by Clark (1998), Tables 2 and 3 show that the woman in both these texts is more Active than the man and also has a much larger participation presence. McCartney functions as participant in the clauses considerably less often than Mills. However, more 'Active' roles and higher levels of participation do not necessarily translate as more positive representation of women. 
As a minor character, McCartney's main function, at least in The Sun, is to allow the writer to emphasise Mills' negative character by quoting the judge '...comparing Paul's character to hers', as in

(carrier) He (proc:rel-att) was (attribute) consistent, accurate and honest... I (proc:verbal) cannot say (verbiage) the same about the wife's evidence.

\begin{tabular}{|l|l|l|l|l|}
\hline & Mills & \% & McCartney & \% \\
\hline Actor (+goal) & 17 & 13 & 6 & 16 \\
\hline Actor (-goal) & 26 & 21 & 2 & 5 \\
\hline Sayer & 23 & 18 & 5 & 14 \\
\hline Senser & 1 & 1 & 0 & 0 \\
\hline Attributor & 1 & 1 & 0 & 0 \\
\hline Initiator & 0 & 0 & 2 & 5 \\
\hline ACTIVE TOTAL & $\underline{68}$ & $\underline{\mathbf{5 4}}$ & $\mathbf{1 5}$ & $\mathbf{4 1}$ \\
\hline Goal & 8 & 6 & 5 & 14 \\
\hline Beneficiary & 4 & 3 & 0 & 0 \\
\hline Scope & 0 & 0 & 1 & 3 \\
\hline Target & 9 & 7 & 3 & 8 \\
\hline Receiver & 2 & 2 & 0 & 0 \\
\hline Verbiage* & 7 & 6 & 0 & 0 \\
\hline Phenomenon & 3 & 2 & 1 & 3 \\
\hline Carrier & 18 & 14 & 3 & 8 \\
\hline Attribute & 1 & 1 & 2 & 5 \\
\hline Token & 1 & 1 & 2 & 5 \\
\hline Value & 2 & 2 & 2 & 5 \\
\hline Existent & 0 & 0 & 0 & 0 \\
\hline Circumstance* & 3 & 2 & 3 & 8 \\
\hline TOTAL & $\mathbf{1 2 6}$ & & $\mathbf{3 7}$ & \\
\hline
\end{tabular}

Table 2: Transitivity concordances for The Sun

(* verbiage/circumstance only include instances where the participants mentioned do not form any other part of the clause, and do not feature in any embedded clauses...etc that are treated as separate processes)

This more Active role is especially pronounced for Sayer in both texts, and for Actor (-Goal) in The Sun, a role Mills fills 26 times, and McCartney only twice. The implications of Actor (-Goal)'s less dynamic role will be dealt with below. However, some reasons for the differences between tabloid and broadsheet (in The Guardian, McCartney is proportionally more likely to be Actor (-Goal)), are worth explaining. They largely seem 
to be a result of the tabloid's tactic of associating Mills with the excessive spending and receiving of money.

\begin{tabular}{|l|l|l|l|l|}
\hline & Mills & $\mathbf{\%}$ & McCartney & $\%$ \\
\hline Actor (+goal) & 12 & 16 & 3 & 11 \\
\hline Actor (-goal) & 7 & 9 & 4 & 14 \\
\hline Sayer & 14 & 19 & 3 & 11 \\
\hline Senser & 7 & 9 & 0 & 0 \\
\hline Attributor & 1 & 1 & 0 & 0 \\
\hline Initiator & 0 & 0 & 0 & 0 \\
\hline ACTIVE TOTAL & $\mathbf{4 1}$ & $\mathbf{5 5}$ & $\mathbf{1 0}$ & $\underline{\mathbf{3 6}}$ \\
\hline Goal & 5 & 7 & 3 & 11 \\
\hline Beneficiary & 1 & 1 & 0 & 0 \\
\hline Scope & 0 & 0 & 1 & 4 \\
\hline Target & 7 & 9 & 1 & 4 \\
\hline Receiver & 0 & 0 & 0 & 0 \\
\hline Verbiage * & 3 & 4 & 1 & 4 \\
\hline Phenomenon & 1 & 1 & 0 & 0 \\
\hline Carrier & 11 & 15 & 6 & 21 \\
\hline Attribute & 1 & 1 & 1 & 4 \\
\hline Token & 1 & 1 & 0 & 0 \\
\hline Value & 0 & 0 & 1 & 4 \\
\hline Existent & 1 & 1 & 1 & 4 \\
\hline Circumstance * & 2 & 3 & 3 & 11 \\
\hline TOTAL & $\mathbf{7 4}$ & & $\mathbf{2 8}$ & \\
\hline
\end{tabular}

Table 3: Transitivity concordances for The Guardian

( ${ }^{*}$ verbiage/circumstance only include instances where the participants mentioned do not form any other part of the clause, and do not feature in any embedded clauses...etc that are treated as separate processes)

\subsection{MONEY}

As is clear from Table 4, The Sun refers to money in any form far more frequently than The Guardian, even when taking into account the relative differences in size of the two texts. In The Guardian it features less in Material Processes (which involve spending or receiving money) and more often as Phenomenon or Attribute (usually describing the worth of something). 


\begin{tabular}{|l|l|l|l|l|l|l|l|l|}
\hline & Goal & Scope & Phenomenon & Carrier & Attribute & Verbiage & Circumstance & TOTAL \\
\hline The Sun & 3 & 19 & 0 & 0 & 2 & 2 & 3 & $\mathbf{2 9}$ \\
\hline Guardian & 0 & 3 & 3 & 0 & 3 & 1 & 1 & $\mathbf{1 1}$ \\
\hline
\end{tabular}

Table 4: Money

In The Sun, money is generally Scope. In 17 out of 19 instances Mills is Actor, hence the frequency with which she appears as Actor (-Goal). Additionally, on the three occasions where she is not the Actor in money-related processes, she is Beneficiary. On both the occasions where money appears in The Sun as Verbiage Mills is Sayer (i.e. she is 'demanding' cash). Therefore, much of Mills' dominant Actor status in the tabloid is negative, implying greed, rather than having any impact on the real world. The few Goals that Mills does act upon include 'victims', e.g. when she pours water over a lawyer. McCartney's goals, on the other hand, are largely music-based, as in '(actor) Paul (proc:material) began writing (goal) music (circ) again'. Similar negative contexts also apply when Mills is in the role of Sayer.

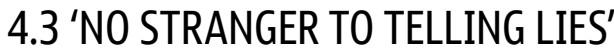

Table 5 reveals that the Court (judges, lawyers and court officials) is the main Sayer in both texts. Considering that The Guardian's is the shorter text, however, the Court is given voice proportionally more often in that paper. The Guardian's focus is relatively more often on legal proceedings and the courtroom, as compared to The Sun's.

\begin{tabular}{|l|l|l|l|l|l|l|}
\hline & Mills & McCartney & Both & Court* & 0ther & TOTAL \\
\hline The Sun & 23 & 5 & 2 & 27 & 5 & $\mathbf{6 2}$ \\
\hline Guardian & 13 & 3 & 0 & 26 & 2 & $\mathbf{4 4}$ \\
\hline
\end{tabular}

Table 5: Sayers

$*^{\prime}$ Court' $=$ references to lawyers, judges, rulings...etc

In The Sun Mills is depicted as Sayer almost as often as is the Court. There is a to-and-fro pattern to their shared Verbal participation. Most of these are instances of Mills' 'boasting', 'moaning' or 'lying', followed by the judge (or writer) dismissing such claims. There is a similar pattern in The Guardian, but the processes describing the judge dismissing these claims are voiced less emotively (as are all Verbal Processes, hence the 'plain' verb say/said/saying is used 23 times). The Guardian avoids the extra evaluation found in The Sun, such as 'Mills is no stranger to telling lies'. The picture of Mills that emerges from the tabloid is of a 'bad girl' who did not do what she was told, lied too often, took large sums of money and wanted more still. This is less pronounced 
in The Guardian, which employs less evaluative language, and does not associate her so often with money.

\subsection{NOMINATION}

On 14 out of the 26 occasions on which she is nominated, Mills is referred to by the nicknames 'Mucca' and 'Pornocchio'. Both nicknames are created by The Sun, and clearly derogatory. 'Mucca', which was penned when details of her nude photos emerged some months before, is both a corruption of her husband's inoffensive nickname 'Macca' and a reference to her 'mucky' past. 'Pornocchio' plays both on her reputation for lying and the aforementioned pornography. Neither of these names appears in The Guardian versions. She is systematically defined in The Sun in terms of her relations to her husband, her 'lying', and her supposed promiscuity.

\subsection{CATEGORISATION}

Tables 6 and 7, below, demonstrate that Mills is functionalised more often than McCartney in both texts (even when we consider these instances as a percentage of total categorisation). This is relatively truer of The Sun than of The Guardian.

\begin{tabular}{|l|l|l|l|l|l|l|l|}
\hline & Mills & McCartney & Both & Judge...etc & Media & Other & TOTAL \\
\hline Functionalisation & $9(45 \%)$ & $2(29 \%)$ & & $10(44 \%)$ & & $7(44 \%)$ & $\mathbf{2 8}$ \\
\hline $\begin{array}{l}\text { Physical } \\
\text { Identification }\end{array}$ & 0 & 0 & & & & $1(6 \%)$ & $\mathbf{1}$ \\
\hline $\begin{array}{l}\text { Relational } \\
\text { Identification -in } \\
\text { relation to Mills }\end{array}$ & - & $1(14 \%)$ & & & & $2(13 \%)$ & $\mathbf{3}$ \\
\hline - to McCartney & $5(25 \%)$ & - & & $2(9 \%)$ & & $5(31 \%)$ & $\mathbf{1 2}$ \\
\hline - to both & - & - & 1 & & & $1(6 \%)$ & $\mathbf{2}$ \\
\hline $\begin{array}{l}\text { Classification - } \\
\text { court actors? }\end{array}$ & $1(5 \%)$ & 0 & & $11(48 \%)$ & & & $\mathbf{1 2}$ \\
\hline Marriage/gender & $5(25 \%)$ & $3(43 \%)$ & & & & & $\mathbf{8}$ \\
\hline Age & 0 & $1(14 \%)$ & & & & & 1 \\
\hline TOTAL & 20 & 7 & 1 & 23 & & 16 & 67 \\
\hline
\end{tabular}

Table 6: Categorisation in The Sun

However, a more careful reading again suggests this does not equate as more positive representation in the tabloid. Of the 9 occasions on which Mills is functionalised in The Sun, nearly all are negative. The text chooses to label her an 'ex-porn model' (on the basis that she appeared in some nude photos many years previously) rather than as a model or campaigner - her current jobs and the roles for which she is far better 
known. Other instances of functionalisation are voiced as her own claims ('I was his full-time wife, mother... business partner and psychologist') and dismissed/ridiculed shortly afterwards ('But the judge scoffed at her claims'). This is a pattern employed throughout both texts, and we find The Guardian also dismissing the one case of 'female' functionalisation as 'make believe', though only through the mouth of the judge.

\begin{tabular}{|l|l|l|l|l|l|l|l|}
\hline & Mills & McCartney & Both & Judge...etc & Media & 0ther & TOTAL \\
\hline Functionalisation & $1(10 \%)$ & 0 & & $10(44 \%)$ & 3 & & $\mathbf{1 4}$ \\
\hline Physical Identification & 0 & 0 & & & & & \\
\hline $\begin{array}{l}\text { Relational } \\
\text { Identification - in } \\
\text { relation to Mills }\end{array}$ & - & $1(25 \%)$ & & & & $1(17)$ & $\mathbf{2}$ \\
\hline - to McCartney & $1(10 \%)$ & - & & $1(4 \%)$ & & $4(67)$ & $\mathbf{6}$ \\
\hline - to both & - & - & & & & $1(17)$ & $\mathbf{1}$ \\
\hline $\begin{array}{l}\text { Classification - court } \\
\text { actors? }\end{array}$ & $2(20 \%)$ & 0 & 1 & $12(52 \%)$ & & & $\mathbf{1 5}$ \\
\hline Marriage/gender & $6(60 \%)$ & $3(75 \%)$ & & & & & $\mathbf{9}$ \\
\hline Age & 0 & 0 & & & & & \\
\hline TOTAL & 10 & 4 & 1 & 23 & 3 & 6 & 47 \\
\hline
\end{tabular}

Table 7: Categorisation in The Guardian

In both texts Mills is classified more frequently as both a court-actor and in terms of marriage/gender (e.g. 'the wife'). In The Sun, relationally, Mills is referred to five times as belonging to McCartney in some way, whereas the opposite - McCartney belonging to Mills - occurs only once. This does prima facie seem deliberate. Despite McCartney's smaller presence, both texts identify other people in relation to him much more frequently than in relation to Mills, especially The Sun's. McCartney is, in terms of his 'ownership' of other people at least, presented as a more dynamic character than Mills.

\subsection{APPRAISEMENT}

Clearer conclusions may be drawn from the appraisement analysis summarised in Tables 8 and 9 below. The Guardian's appraisement is minimal in comparison to The Sun's. All four instances where it does occur in The Guardian are 'borrowed' quotes (e.g. 'Mills' charitable giving', 'own worst enemy'). However, it is also worth noting that it is Mills alone who is subjected to any appraisement at all in the broadsheet.

\begin{tabular}{|l|l|l|l|}
\hline & Mills & McCartney & Other \\
\hline Positive & 2 & 3 & 3 \\
\hline Negative & 11 & 0 & 1 \\
\hline
\end{tabular}

Table 8: Appraisement in The Sun 


\begin{tabular}{|l|l|l|l|}
\hline & Mills & McCartney & Other \\
\hline Positive & 1 & 0 & 0 \\
\hline Negative & 3 & 0 & 0 \\
\hline
\end{tabular}

Table 9: Appraisement in The Guardian

The Sun's appraisement is far more extensive, and it is disproportionate. 11 out of 12 instances of negative appraisement are focused on Mills. McCartney is only referred to positively in terms of appraisement. The two positive examples referring to Mills ('tireless charity campaigner and fundraiser'; 'his full-time wife, mother, lover...') are claims included solely to be dismissed/ridiculed in subsequent but clauses (e.g. 'But tax returns showed she donated NOTHING'; 'But the judge scoffed at her claims'). We can gather from this comparison that the disproportionate amount of negative appraisement Mills suffers in The Sun could be said to reflect a male chauvinistic bias.

\subsection{ADDITIONAL FEATURES}

The general value-system employed in The Sun centres on honesty and greed. Where McCartney is described as 'consistent, accurate and honest', Mills is portrayed as a liar, and is even awarded a nickname based on this alleged dishonesty. She is frequently represented as spending or demanding too much money, whereas McCartney is often described as paying or buying things for her e.g. '(goal) a flash $€ 3$ million house (actor) he (proc:material) bought (beneficiary) for her and Beatrice'. While these processes may represent real events, the Sun's persistent emphasis on financial matters appears excessive when compared to the Guardian's coverage, where any evaluation is largely expressed only through the judge's own statements.

Finally, the use of photos and captions is worthy of comment as it complements this negative portrayal. All the main social actors in the tabloid are pictured, but two of the three photos of Mills are very suggestive: one is a doctored photo of her with a big nose, labeled 'Pornocchio'; the other is an old photo of her in a nude shot. The third photo of her is accompanied with the caption 'underhand'. This seems to deliberately contrast with the caption employed with the sole photo of McCartney, namely 'sombre'. The broadsheet, for its part, has just one picture, which features Mills fully clad and in a court setting.

\section{CONCLUSION}

While Mills is not more often referred to in terms of physical-identification than McCartney, she is described more in terms of her relational-identification to him than vice-versa, and she suffers a great deal more negative appraisement. With regard to nomination it is Mills, again, who is referred to considerably more often than the man in informal terms or by offensive nicknames in The Sun, while the opposite occurs in The Guardian. She is functionalised more often in both texts, but much of this is ironic and/ or sexual in the tabloid, or stated there merely to be dismissed. The divergent patterns in The Guardian highlight the fact that this is essentially a choice on The Sun's part, possibly reflective of the differing ideologies of the two newspapers. 
Our transitivity analysis reveals Mills to be the more Active participant in both texts, which runs counter to what an investigation into sexism would traditionally expect. However, this more dominant presence is largely a negative one. In fact, it is her dominance itself in the tabloid which is criticized, as in '...no one tells the wife what to do' and '[she is] her own worst enemy. She has an explosive and volatile character'. For feminists this might ring alarm bells. It sounds very much as though the only husband-wife relationship acceptable to The Sun would be one in which the wife is subservient. Why else would Mills' strong character be so roundly condemned, where such a trait would undoubtedly be welcomed by the same newspaper in a British soldier or sports hero? Moreover, Mills is made a frequent Sayer only to show what a 'liar' she is. Similarly, she is often accorded the role of Actor in the tabloid only to portray her as unreasonably demanding money. The overall message appears to be that a woman should not expect to have these rights. Certainly, it is safe to conclude that this negative portrayal of Mills is a great deal more prominent in The Sun than in the broadsheet version of events.

It seems that The Sun's modus operandi in ideological dissemination has hardly altered for decades. It includes 0thering/outsidering as a central strategy and 'friends' and 'outsiders' are overtly juxtaposed and compared - in this case, McCartney vs Mills, or 'Macca' vs 'Mucca' but, more generally, male against female. Fine nuances of fact seem to be readily discounted. Arguably, all that matters is that the opposing parties in a given conflict provide vehicles that parallel the stereotypes of friend and outsider and, therefore, serve to reinforce a pre-existing position on the part of the newspaper. In The Sun, this position appears to be a remarkably reactionary one.

\section{REFERENCES}

Benwell, B. 2002. Is there anything 'new' about these lads? The textual and visual construction of masculinity in men's magazines. In L. Litosseliti \& J. Sunderland (eds.) Gender Identity and Discourse Analysis: Discourse approaches to politics, society and culture. Amsterdam: John Benjamins, 149-176.

Black, M. \& Coward, R. 1998. Linguistic, social and sexual relations: a review of Dale Spender's Man Made Language. In D. Cameron (ed.) The Feminist Critique of Language: $A$ reader ( $2^{\text {nd }}$ edition). London: Routledge, 100-118.

Buikema, R. \& Van der Tuin, I. (eds.). 2009. Doing Gender in Media, Art and Culture. London: Routledge.

Butler, J. 1990. Gender Troubles: feminism and the subversion of identity. London: Routledge.

Caldas-Coulthard, C.R. 1996. Women who pay for sex. And enjoy it: transgression versus morality in women's magazines. In C. R. Caldas-Coulthard \& M. Coulthard (eds). Texts and Practices: Readings in critical discourse analysis. London: Routledge, 250-270.

Cameron, D. 2001. Working with Spoken Discourse. London: Sage.

Clark, K. 1998. The Linguistics of Blame: Representations of women in The Sun's reporting of crimes of sexual violence. In D. Cameron (ed.) The Feminist Critique of Language: A reader ( $2^{\text {nd }}$ edition). London: Routledge, 183-197. 
Halliday, M.A.K. 1985/94. An Introduction to Functional Grammar. London: Edward Arnold Hawes, T. 2010. Horror bodies: the disapproved of. Luminary 2, 4-13.

Hunston, S. \& Thompson, G. (eds.) 2000. Evaluation in Text: Authorial stance and the construction of discourse. Oxford: 0UP.

Jule, A. 2008. A Beginner's Guide to Language and Gender. Clevedon: Multilingual Matters.

Litosseliti, L. 2002. Head to head: gender repertoires in newspaper arguments. In L. Litassoleti \& J. Sunderland (eds.) Gender Identity and Discourse Analysis: Discourse approaches to politics, society and culture. Amsterdam: John Benjamins, 129-148.

Litosseliti, L. \& Sunderland, J. (eds.) 2002a. Gender Identity and Discourse Analysis: Discourse approaches to politics, society and culture. Amsterdam: John Benjamins.

Litosseliti, L. \& Sunderland, J. 2002b. Gender identities and discourse analysis theoretical and empirical considerations. In L. Litosseliti \& J. Sunderland (eds.) Gender Identity and Discourse Analysis: Discourse approaches to politics, society and culture. Amsterdam: John Benjamins, 1-39.

Marshment, M. 1993. The picture is political: representation of women in contemporary popular culture. In D. Richardson \& V. Robinson (eds.) Women's Studies. Hong Kong: Macmillan, 123-150.

Mulvey, L. 1975. Visual pleasure and narrative cinema. Screen 16.3, 6-18.

NRS. 2010. NRS Readership estimates - Newspapers and supplements: July 2009 - 2010'. [Internet]. Available at: http://www.nrs.co.uk/toplinereadership.html [16.06.2010].

Opinion Matters. 2010. Wake Up To Rape Research Summary Report. [Internet]. Available at: http://www.thehavens.co.uk/docs/Havens_Wake_Up_To_Rape_Report_Summary. pdf [20.05.2010].

Richardson, J. 2007. Analysing Newspapers: An approach from critical discourse analysis. Basingstoke: Palgrave Macmillan.

Thompson, G. 2004. Introducing Functional Grammar. $2^{\text {nd }}$ edition. London: Hodder Education.

van Leeuwen, T. 1996. The representation of social actors. In C. R. Caldas-Coulthard and M. Coulthard (eds.) Texts and Practices: Readings in critical discourse analysis, London: Routledge, 32-70.

\section{SUMMARY}

\section{HONESTY VS GREED, MACCA VS MUCCA: OTHERING IN TWO BRITISH NEWSPAPERS}

Feminists have long condemned the trivialisation and sexualisation of women in British newspapers but have perhaps focused too little on what sometimes appears to be a veritable demonisation of high-profile women. For example, the death of Amy Winehouse in summer 2011 seems prima facie not entirely unrelated to the years of vilification she was subjected to, especially in The Sun. This study therefore conducts a comparative examination into the Othering of Heather Mills, ex-wife of Paul McCartney, in parallel articles from The Sun and The Guardian. To produce a multilayered linguistic analysis we employ a range of functional-grammatical tools: transitivity to 
compare the roles allotted to Mills and McCartney; nomination to see how they are named; categorisation regarding the stereotypes with which they are associated; and appraisement to show whether they are depicted positively or negatively. The results suggest that there is a serious imbalance in the portrayal of these two celebrities. We ask why this might be. Is Mills that monstrous, McCartney that angelic? Or is it that a divorce scenario, pitting hero against villain, provides a perfect vehicle for indirect dissemination of the newspaper's ideology and the expression of a pre-existing message? media.

KEYWORDS: critical discourse analysis, functional grammar, language and the (Original scientific paper received 14.04.2012; revised 18.11.2012; accepted 20.11.2012) 